\title{
Presence and diversity of Chlamydiae bacteria in Spinturnix myoti, an ectoparasite of bats
}

\author{
Kevin Thiévent ${ }^{1}$, Tamara Szentiványi ${ }^{2,3}$, Sébastien Aeby ${ }^{1}$, Olivier Glaizot ${ }^{2,3}$, Philippe Christe $^{3}$, and Gilbert Greub ${ }^{1, *}$ \\ ${ }^{1}$ Center for Research on Intracellular Bacteria (CRIB), Institute of Microbiology, University Hospital Center and University of Lausanne, \\ 1011 Lausanne, Switzerland \\ ${ }^{2}$ Museum of Zoology, 1005 Lausanne, Switzerland \\ ${ }^{3}$ Department of Ecology and Evolution, University of Lausanne, 1015 Lausanne, Switzerland
}

Received 31 March 2020, Accepted 7 October 2020, Published online 2 November 2020

\begin{abstract}
Chlamydia spp. and Chlamydia-like organisms are able to infect vertebrates such as mammals, reptiles and birds, but also arthropods and protozoans. Since they have been detected in bats and bat feces, we expected Chlamydiae bacteria to also be present in the mite Spinturnix myoti, an ectoparasite of mouse-eared bats (Myotis spp.). The prevalence of Chlamydiales in $88 \mathrm{~S}$. myoti was $57.95 \%$ and significantly depended on bat host species. In addition, the prevalence was significantly different between bat species living in sympatry or in allopatry. While there was uninterpretable sequencing for 16 samples, eight showed best BLAST hit identities lower than $92.5 \%$ and thus corresponded to new family-level lineages according to the established taxonomy cut-off. The four remaining sequences exhibited best BLAST hit identities ranging from 94.2 to $97.4 \%$ and were taxonomically assigned to three different family-level lineages, with two of them belonging to the Parachlamydiaceae, one to the Simkaniaceae, and one to the Chlamydiaceae. These results highlighted for the first time the presence of Chlamydia-like organisms and the possible zoonotic origin of Chlamydia sp. in S. myoti ectoparasites of bats, and therefore suggest that these ectoparasites may play a role in maintaining and/or transmitting members of the Chlamydiae phylum within Myotis spp. bat populations. Our results further highlight that the wide diversity of bacteria belonging to the Chlamydiae phylum is largely underestimated.
\end{abstract}

Key words: Chlamydiae, Mites, Bats, Vector, Epidemiology, Phylogenetic analysis.

Résumé - Présence et diversité des bactéries Chlamydiae chez Spinturnix myoti, un acarien ectoparasite de chauve-souris. Les Chlamydia spp. et les organismes apparentés aux Chlamydia sont capables d'infecter des vertébrés tels que les mammifères, les reptiles et les oiseaux mais aussi des arthropodes et des protozoaires. Puisqu'elles ont été détectées dans des chauves-souris et des excréments de chauves-souris, nous nous attendions à ce que les bactéries du phylum Chlamydiae soient également présentes dans des Spinturnix myoti, des acariens ectoparasites de chauves-souris du groupe des murins (Myotis spp.). La prévalence des Chlamydiales dans 88 S. myoti était de $57,95 \%$ et dépendait de manière significative des espèces hôtes de chauves-souris. De plus, la prévalence était significativement différente entre les chauves-souris vivant en sympatrie ou en allopatrie. Alors qu'il y avait un séquençage ininterprétable pour 16 échantillons, huit présentaient des résultats d'analyse de type de type BLAST avec une similarité inférieure à $92.5 \%$ et à $92,5 \%$ et correspondaient donc à de nouvelles familles selon les seuils utilisés en taxonomie par les chlamydiologistes. Les quatre séquences restantes présentaient des résultats BLAST allant de 94,2 à 97,4 \% et ont été taxonomiquement attribuées à trois familles ; deux d'entre elles appartenant aux Parachlamydiaceae, une aux Simkaniaceae et enfin une aux Chlamydiaceae. Ces résultats ont mis en évidence pour la première fois la présence d'organismes de type Chlamydia mais aussi d'organisme pouvant amener à des zoonoses tel que Chlamydia sp. chez Spinturnix myoti, un ectoparasite de chauves-souris. Ces résultats suggèrent donc que ces ectoparasites pourraient jouer un rôle dans le maintien et/ou la transmission des membres de l'embranchement des Chlamydiae au sein des populations de chauves-souris du genre Myotis. Nos résultats soulignent en outre que la grande diversité des bactéries appartenant à l'embranchement des Chlamydiae est largement sous-estimée.

\footnotetext{
*Corresponding author: gilbert.greub@chuv. ch
} which permits unrestricted use, distribution, and reproduction in any medium, provided the original work is properly cited. 


\section{Introduction}

Chlamydiae are obligate intracellular bacteria known to cause medically and economically important infectious diseases. There are nine recognized families of Chlamydiae within the Chlamydiales order: Parachlamydiaceae, Criblamydiaceae, Rhabdochlamydiaceae, Waddliaceae, Simkaniaceae, Piscichlamydiaceae, Clavichlamydiaceae, Parilichlamydiaceae and Chlamydiaceae [16, 21, 57]. Chlamydiaceae includes two well-known human pathogens, Chlamydia trachomatis and $C$. pneumoniae, but also includes other animal pathogens responsible for zoonotic infections such as $C$. psittaci and C. abortus [5, 30], the causative agents of psittacosis and sheep abortion, respectively. Chlamydia trachomatis is responsible for sexually transmitted infections worldwide but also causes trachoma, a blinding disease in developing countries [2, 35, 54], while Chlamydia pneumoniae is an agent responsible for respiratory infections [37]. While members of the Chlamydiaceae family are known to be human and/or animal pathogens and are thus highly studied, the role of bacteria belonging to the eight other family-level lineages (also called Chlamydia-like organisms (CLOs)) requires further investigations. Waddlia chondrophila, a member of the Waddliaceae family, has recently been associated with miscarriage and tubal infertility [3, 4, 60], while Simkania negevensis, Rhabdochlamydia spp. and Parachlamydia spp. have been associated with respiratory infections [15, 24, 27, 36, 39].

Chlamydiae have been found in a wide variety of environmental samples such as water and soil, but also in different organisms such as mammals, reptiles and birds, as well as in arthropods and protozoans [30, 40, 43, 55]. Recently, CLOs and other members of the Chlamydiaceae family have been discovered in bats. Two fruit bat species were found to harbor bacteria from the Waddliaceae family, with Waddlia malaysiensis found in the urine of Eonycteris spelaea (Chiroptera: Pteropodidae) in Peninsular Malaysia [13] and Waddlia cocoyoc found in skin biopsies of Artibeus intermedius (Chiroptera: Phyllostomidae) in Mexico [41]. A recent study found that more than $50 \%$ of the feces samples of the bat Myotis daubentonii (Chiroptera: Vespertilionidae) carried members of the Chlamydiae phylum in Finland, with most of the positive samples belonging to two main families, the Rhabdochlamydiaceae and the Chlamydiaceae [29]. These studies suggested that bats may act as reservoirs for Chlamydia and CLOs, in addition to other pathogens such as Bartonella [59], Ebola or SARS [10, 26]. Indeed, colonial habits of bats, in particular during the reproductive season when females aggregate in huge numbers to form nursery colonies, make them particularly susceptible to pathogens and parasites [11]. Although bats seem to be colonized by various members of the Chlamydiae phylum, whether these strict intracellular bacteria are transmitted between bats is yet unknown. However, ectoparasites of bats may be suitable vector candidates for Chlamydiae bacteria.

Spinturnix mites are obligate hematophagous ectoparasites of bats and are found on the membranous regions of their host's body, mainly the wing membranes [47]. Spinturnix mites are not able to survive away from their host more than a few hours [23] and are viviparous, a life history strategy that has been proposed to facilitate vertical pathogen transmission [11]. Thus, their ecology and feeding biology makes them good candidates to transmit and maintain Chlamydiae within and between bat populations.

The aim of this study was to evaluate the distribution and diversity of Chlamydiae in Spinturnix mites and to reveal their reservoir or vectorial potential for Chlamydiae in bats. To do so, we first screened Spinturnix myoti, a species that is specialized on mouse-eared bats (Myotis spp.), for the presence of Chlamydiae. We then compared the Chlamydiae prevalence between three different Myotis bat species on which mites were collected, and between the six different countries where they were collected. Finally, some of the $16 \mathrm{~S}$ rRNA genes of positive results were sequenced and submitted to a BLAST analysis.

\section{Methods}

\section{Spinturnix sampling and DNA purification}

Bats were captured and Spinturnix ectoparasites were collected in 1998, 2005 and 2006 before the Nagoya convention (2010), and thus no specific authorizations were needed. Ectoparasites were placed in $98 \%$ ethanol and kept at $-20{ }^{\circ} \mathrm{C}$ until further processing. Collection sites were located in North Africa, such as Tunisia and Morocco, as well as in Europe, including France, Italy, Spain and Switzerland. Spinturnix mites were identified using different morphological keys [18, 19, 49]. Spinturnix myoti specimens were retrieved from the lesser and the greater mouse-eared bats, respectively M. blythii (Italy (Piemonte), Switzerland (Valais)) and M. myotis (Italy (Piemonte), Spain (Andalousia, La Fajara), Switzerland (Jura, Valais, Vaud)) and from the Maghreb mouseeared bat Myotis punicus (France (Corsica), Italy (Sardinia), Morocco, Tunisia). Myotis myotis and M. blythii live in sympatry throughout Europe and frequently form mixed species colonies (here, Piemonte and Valais). These two species have never been found in sympatry with $M$. punicus. DNA extraction from each sample was performed using a standard proteinase K-phenol chloroform method [48].

\section{Pan-Chlamydiales real-time PCR and sequencing}

A real-time quantitative PCR specific to Chlamydiales performed with a StepOne Plus real-time PCR system (Applied Biosystems, Zug, Switzerland) was used to detect Chlamydiales DNA [37]. Specific forward primer panChl16F2, 5'-CCGCCAACACTGGGACT- $3^{\prime}$ (the underlined nucleotides represent locked nucleic acids) and reverse primer panChl16R2, 5'-G GAGTTAGCCGGTGCTTCTTTAC- $-3^{\prime}$, amplified a DNA fragment of about $200 \mathrm{bp}$ (size is species-dependent) belonging to the Chlamydiales $16 \mathrm{~S}$ ribosomal RNA-encoding gene, and these fragments were detected using a pan-Chlamydiales specific probe, 5'-FAM [6-carboxfluorescein]-CTACGGGAGGCTGCAGTCGAGGATC-BHQ1 [black hole quencher 1]-3'. Amplifications were performed in a final volume of $20 \mu \mathrm{L}$ with iTaq Universal Probes Supermix with ROX (BioRad, Reinach, Switzerland), $0.1 \mu \mathrm{M}$ of each primer and of the probe, and with $5 \mu \mathrm{L}$ of sample DNA. DNA was amplified after initial denaturation and activation of $3 \mathrm{~min}$ at $95^{\circ} \mathrm{C}$ for 40 
cycles with denaturation, annealing and extension occurring at $95^{\circ} \mathrm{C}, 67^{\circ} \mathrm{C}$ and $72{ }^{\circ} \mathrm{C}$, respectively and each step lasting $15 \mathrm{~s}$. Standard curves were built using a serial dilution of positive control plasmids (ten-fold diluted from $10^{5}$ to 5 copies). Each Spinturnix DNA sample was tested in duplicate in 96-well plates, along with standard dilutions in duplicate, two negative controls and two extraction controls. Only samples with a threshold cycle value $\left(C_{t}\right)$ smaller than 35 were sent to Microsynth (Balgach, Switzerland) for Sanger sequencing, since a $C_{t}$ of 35 is the observed threshold for amplicon sequencing we documented in our laboratory. Although they were not sent for sequence analysis, the samples with $C_{t}$ higher than 35 were also considered positive since the PCR used in this study was highly specific [37].

\section{Phylogeny}

The partial 16S rRNA regions sequenced here in addition to referenced sequences of the 16S rRNA genes of different Chlamydiales and an outgroup taxa (Opitutus terrae, a member of the order Verrucomicrobiales, which has previously been used as an outgroup of all Chlamydiales [50]) were aligned using the MUSCLE plug-in [20] with Geneious software [34]. Using this alignment and the MrBayes plug-in [32], we built a Bayesian posterior-probability consensus tree with a total chain length of $1,100,000$ and a burn-in length of 11,000 , as previously described [29].

\section{GenBank accession numbers}

Assigned accession number for the partial 16S rRNA sequences amplified from $S$. myoti deposited in GenBank are MT844007-MT844018.

\section{Statistical analysis}

Using a general linear model (GLM) with a binomial distribution, prevalence of Chlamydiae within Spinturnix was first compared between $S$. myoti males and females. In this analysis, the proportion of positive samples was set as the response variable, $S$. myoti sex was set as fixed factors and the model was weighted by the total number of samples per group $(N)$.

Using another GLM with a binomial distribution, prevalence of Chlamydiae within Spinturnix was then compared between the bat species on which they were collected. In this analysis, the proportion of positive samples was set as the response variable, the host species were set as fixed factors and the model was weighted by the total number of samples per group $(N)$.

As bats were not always found in sympatry, we compared in a second step the Chlamydiae prevalence between the collection sites (i.e. the country where bats were collected) within each bat species independently. To do this, we ran for each bat species a GLM with a binomial distribution and with the proportion of positive Spinturnix samples set as the response variable, and the country as a fixed factor.

Third, using a GLM with a binomial distribution, we compared the prevalence between Spinturnix mites collected on M. myotis and M. blythii when these later were found in sympatry (in Piemonte (Italy) and Valais (Switzerland)). The host bat species and the collection site were set as a fixed factor with the proportion of positive results set as response variable.

Finally, in order to get a better idea of the role of Spinturnix mites in the transmission of Chlamydiae between bats, we tested whether the fact of living or not in sympatry affected the Chlamydiae prevalence in the Spinturnix mites. To do so, we selected the data from the Spinturnix collected on M. myotis since this was the only bat species found to live both alone or in sympatry. Prevalences of Spinturnix between M. myotis living in sympatry or not were compared using a GLM with a binomial distribution.

All analyses and graphs of prevalence were performed with $\mathrm{R}$ software, version 3.5.2 [44] and its interface Rstudio, version 1.1.463 [46]. Significance of the effects were evaluated using the ANOVA function of the R package "car" [22].

\section{Results}

\section{Chlamydiae prevalence in Spinturnix mites}

Of the 88 Spinturnix myoti, $57.95 \%$ were positive for the presence of Chlamydiae. Spinturnix myoti males and females were equally infected by Chlamydiae with $53.33 \%$ positive females and $57.97 \%$ positive males $\left(\chi^{2}=0.002, d f=1\right.$, $p=0.97$, Table 1). The Chlamydiae prevalence in $S$. myoti significantly varied between the host bat species with $20 \%$ (95\% confidence intervals (CI); 8.1-41.6\%) Myotis blythii, $64.5 \%$ (95\% CI; 46.9-78.9\%) M. myotis, and 73\% (95\% CI; 57-84.6\%) $M$. punicus being positive for Chlamydiae $\left(\chi^{2}=16.2, d f=2, p<0.001\right)$ (Fig. 1).

The results of Chlamydiae prevalence are summarized in Table 1. The Chlamydiae prevalence in S. myoti found on $M$. punicus did not vary significantly between the different countries where the mites were collected $\left(\chi^{2}=3.98, d f=3\right.$, $p=0.26$ ). Similar results were found for the $S$. myoti collected on $M$. blythii, with no difference in prevalence between mites collected in Switzerland and in Italy $\left(\chi^{2}=0.48, d f=1\right.$, $p=0.49$ ). In contrast, the Chlamydiae prevalence in $S$. myoti collected on $M$. myotis significantly varied between the different collection sites $\left(\chi^{2}=11.41, d f=2, p=0.03\right)$, with a prevalence ranging from $40 \%$ (Italy) to $100 \%$ (Spain).

The Chlamydiae prevalence in S. myoti mites was not significantly different between the host bat $M$. myotis and $M$. blythii when these latter were living in sympatry $\left(\chi^{2}=0.21, d f=1, p=0.64\right)$. In fact, $30 \%$ (95\% CI; $10.8-$ $60.3 \%$ ) of the $S$. myoti collected on $M$. myotis harbored Chlamydiae, while the prevalence was $20 \%$ (95\% CI; $8.1-$ $41.6 \%$ ) for the mites collected on $M$. blythii. In addition, there was no effect of the collection site $\left(\chi^{2}=0.95, d f=1, p=0.33\right)$, nor from the interaction between the host species and the collection sites $\left(\chi^{2}=0.01, d f=1, p=0.92\right)$.

Finally, Chlamydiae prevalence was significantly different between $S$. myoti mites collected on $M$. myotis bats living in sympatry and mites collected on M. myotis living in allopatry $\left(\chi^{2}=7.66, d f=1, p=0.006\right)$. In fact, while $80.95 \%(95 \%$ CI; 59.9-92.3\%) of the S. myoti harbored Chlamydiae when 
Table 1. Summary of Chlamydiae prevalence results as a function of sex and life stage of S. myoti and of bat host species and collection sites.

\begin{tabular}{|c|c|c|c|}
\hline & $\begin{array}{c}\text { Number of } \\
\text { tested } \\
\text { S. myoti }\end{array}$ & $\begin{array}{c}\text { Number of } \\
\text { infected } \\
\text { S. myoti }\end{array}$ & $\begin{array}{c}\text { Chlamydiae } \\
\text { prevalence } \\
(\%)\end{array}$ \\
\hline \multicolumn{4}{|c|}{ Sex and life stage of $S$. myoti } \\
\hline Male & 69 & 40 & 57.9 \\
\hline Adult & 55 & 38 & 69.1 \\
\hline Deutonymph & 9 & 2 & 22.2 \\
\hline Stage undetermined & 5 & 0 & 0 \\
\hline Female & 15 & 8 & 53.3 \\
\hline Adult & 10 & 6 & 60 \\
\hline Stage undetermined & 5 & 2 & 40 \\
\hline Sex undetermined & 4 & 3 & 75 \\
\hline Adult & 2 & 2 & 100 \\
\hline Deutonymph & 2 & 1 & 50 \\
\hline \multicolumn{4}{|c|}{ Bat species and collection sites } \\
\hline Myotis punicus & 37 & 27 & 72.9 \\
\hline Corsica & 12 & 10 & 83.3 \\
\hline Sardinia & 15 & 12 & 80 \\
\hline Morocco & 7 & 3 & 42.9 \\
\hline Tunisia & 3 & 2 & 66.7 \\
\hline Myotis myotis & 31 & 20 & 64.5 \\
\hline Spain & 10 & 10 & 100 \\
\hline Italy & 5 & 2 & 40 \\
\hline Switzerland & 16 & 8 & 50 \\
\hline Myotis blythii & 20 & 4 & 20.0 \\
\hline Italy & 7 & 2 & 28.6 \\
\hline Switzerland & 13 & 2 & 15.3 \\
\hline Total & 88 & 51 & 57.95 \\
\hline
\end{tabular}

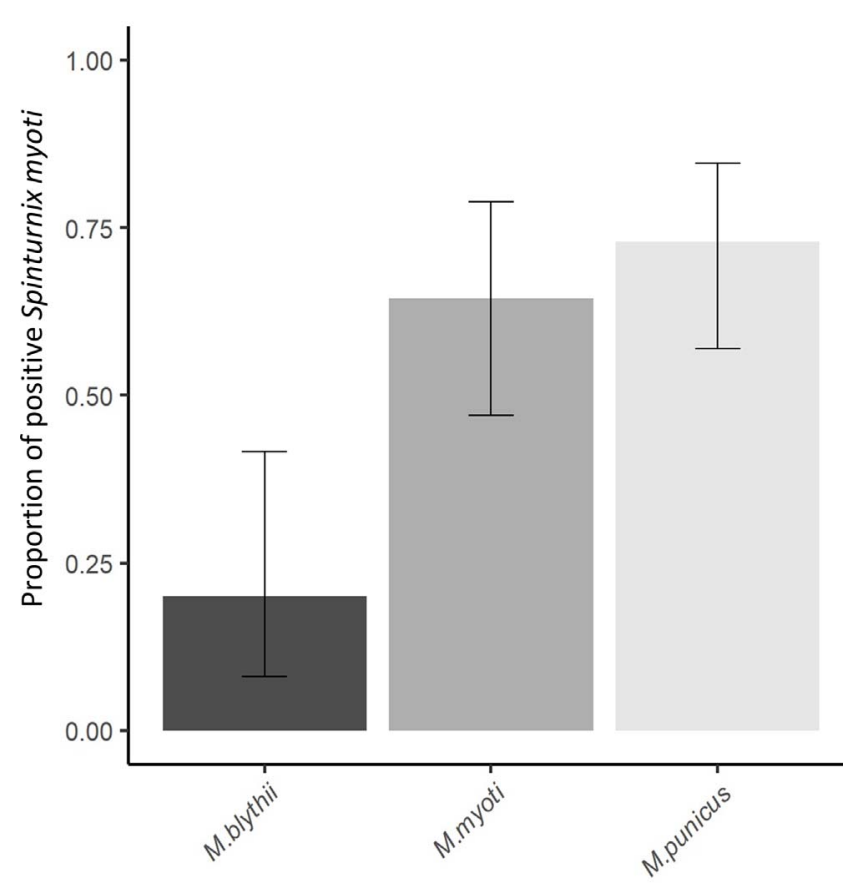

Figure 1. Prevalence of Chlamydiae in Spinturnix myoti as a function of their host species. Bars represent the $95 \%$ confidence intervals.
M. myotis were found alone, only $30 \%$ harbored Chlamydiae when $M$. myoti were living in sympatry with $M$. blythii.

\section{BLAST and phylogenetic analysis}

Of the 51 positive samples, 28 showed $C_{t}$ values lower than 35 and were thus sequenced. Of these, 16 gave uninterpretable sequences (due to low DNA content or to mixed sequences), and 8 showed best BLAST hit identities smaller than $92.5 \%$ and thus correspond to new family-level lineages according to the established taxonomy cut-off [42]. Following this taxonomy cut-off, the 4 remaining samples with best BLAST hits ranging from $94.2 \%$ to $97.4 \%$ were taxonomically assigned at the family-level lineages with two sequences belonging to the Parachlamydiaceae (GenBank accession numbers MT844011 and MT844016) one to the Simkaniaceae (GenBank accession number MT844014) and one to the Chlamydiaceae (GenBank accession number MT844008).

In accordance with the BLAST analysis, the Bayesian phylogenetic tree revealed that most of the sequences that showed BLAST hit identities smaller than $92.5 \%$ were grouped together with a high posterior probability score and seem to form a previously unknown family of Chlamydiales (Fig. 2).

\section{Discussion}

Chlamydia and Chlamydia-like organisms have recently been found in bat samples suggesting that bats may play a role as reservoirs for members of the Chlamydiae phylum $[13,29,41]$. However, the way bats become infected by these Chlamydiae is unclear. Here we found a high prevalence (57.95\%) of Chlamydiae in Spinturnix myoti, an obligate, ectoparasitic mite species of mouse-eared bats (Myotis spp.), suggesting that mites may play a role as reservoirs or vectors. In addition, sequencing and phylogenetic analysis revealed that $S$. myoti mites harbor Chlamydiales from several families including a new family-level lineage, suggesting that the diversity of the Chlamydiales order is underestimated.

Although our knowledge of the epidemiology of the Chlamydiaceae family has increased rapidly due to their zoonotic potential, our understanding is still scarce concerning the ecology, diversity and epidemiology of Chlamydia-like organisms. CLOs are able to infect several organisms including humans [24, 25, 55], but transmission routes remain unknown. Previous studies have highlighted that amoebae may be reservoirs and dispersal vectors of different CLOs species, especially Parachlamydiaceae and Criblamydiaceae [30, 56]. Here, in addition to previous work done on ticks and fleas $[9,17,28$, 43], we confirmed that ectoparasites such as Spinturnix mites may play a role in the transmission of Chlamydiae. However, whether ectoparasites can effectively transmit Chlamydiae is not known and further studies are needed. A previous study showed that Bartonella infection found in humans was closely related to infections found in our target species $S$. myoti, suggesting that bat-associated bacterial pathogens can infect humans [53]. Additionally, other bacterial pathogens or possibly symbionts have been detected from mites, including 


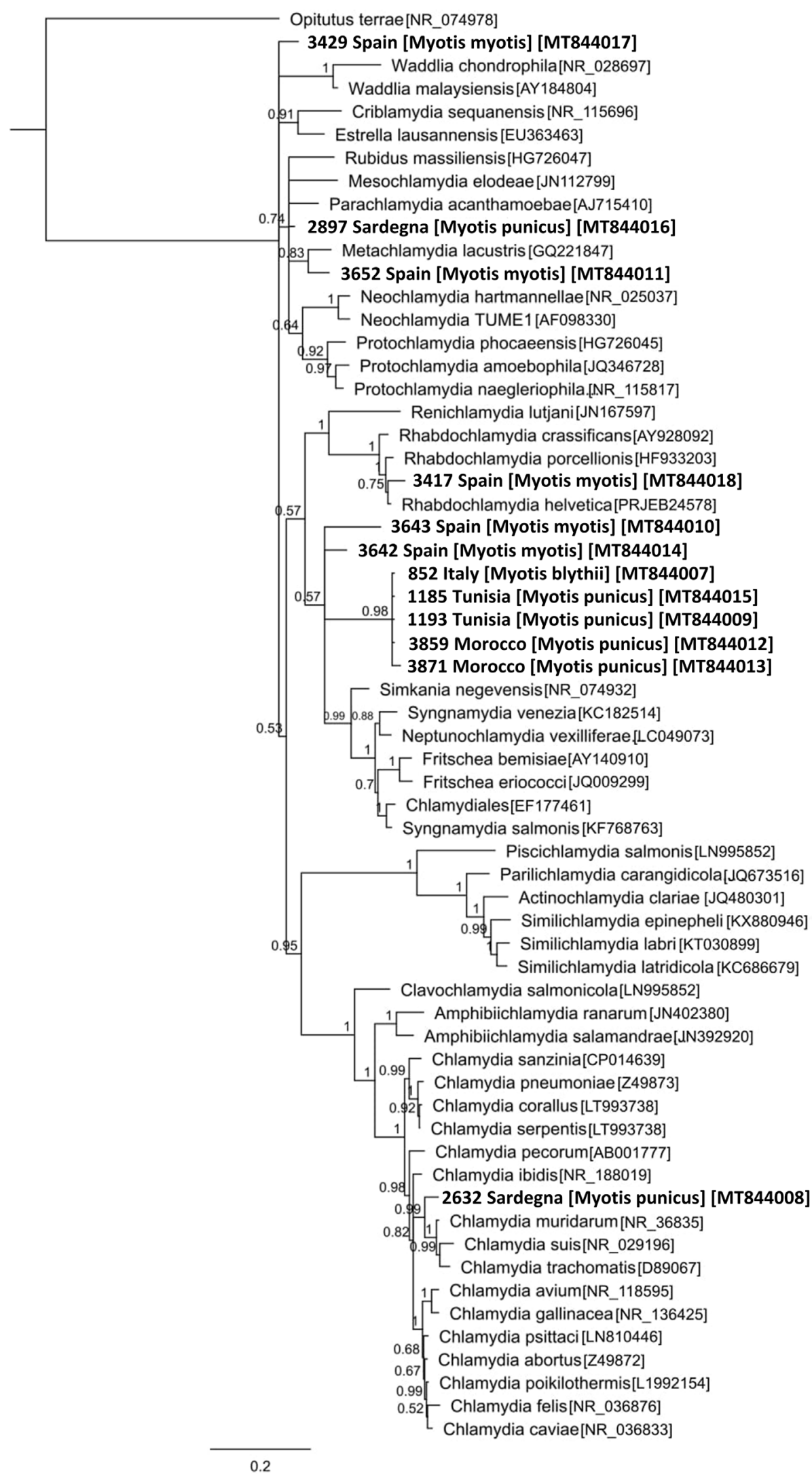

Figure 2. Phylogenetic Bayesian consensus tree of the Spinturnix sequences of this study (in bold) along with Chlamydiales-reference and outgroup sequences (all with their GenBank accession numbers) with the posterior probabilities of clades and the branch length for 16S rRNA. Only posterior probabilities of more than $50 \%$ are shown in the tree. In addition to their reference code, we also added the collection site and the bat host species of each $S$. myoti sequence. 
Spinturnix spp., such as Anaplasma spp., Bartonella spp., Rickettsia spp. and Spiroplasma sp. [31, 45, 53].

Vector feeding preference is one of the most important components determining the distribution of diseases. Vectors that are specialized to take their blood meal from closely related hosts limit the distribution of the microbes they host to regions where they are present. On the other hand, vectors that are more generalists, i.e. feeding on distantly related host species, may favor the spread of pathogenic microbes they can transmit, possibly extending them to new host species. Spinturnix mites are known to display different levels of host specificity, ranging from one to several usually closely related bat species $[1,7$, $8,12]$. Thus, they may play a major role in the distribution and/or maintenance of Chlamydiae bacteria within and between bat populations. In particular, S. myoti is rather specific to mouse-eared bats [57] but can disperse between closely-related species or by accidental transfer when these are in close contact. Importantly, while $M$. punicus are geographically localized in North Africa, Sardinia, Corsica and Malta [33], M. blythii and M. myotis are mainly found in continental Europe, sometimes forming mixed nursery colonies [12]. Despite the potential close contact between M. blythii and M. myotis, the Chlamydiae prevalence was significantly lower in the Spinturnix mites found on M. blythii, which might suggest that $M$. blythii is less vulnerable to Chlamydiae infection than $M$. myotis, and thus that M. blythii may have a lower reservoir potential for Chlamydiae. In addition, the prevalence in Spinturnix was significantly higher when $M$. myotis were living without any other bat species rather than when living in sympatry with M. blythii. This difference in prevalence between allopatric and sympatric M. myotis may reflect a dilution effect with M. blythii playing a role as an incompetent host. However, our results revealed that $20 \%$ of S. myoti collected on M. blythii were harboring Chlamydiae. A possibility may be that these infected $S$. myoti collected on M. blythii acquired their infection on M. myotis first before switching host. Spinturnicid mites are known to often switch between their hosts [23] and may thus carry their Chlamydiae from one host to another. However, since in this study S. myoti were collected on M. blythii only found in sympatry with $M$. myotis, this hypothesis cannot be confirmed. Further studies are thus needed to better understand the reservoir potential of bats for Chlamydiae, since it seems to be species-dependent, with M. blythii exhibiting at least a lower competence for Chlamydiae than M. myotis.

Altogether, these results indicate that $S$. myoti may contribute to the transmission and maintenance of Chlamydiae between bat species. The prevalence in $S$. myoti decreased when there is more than one host bat species, which indicates that the Chlamydiae may be distributed between the different bat species by these mites. In addition, our novel study showed that Chlamydiae infection in Spinturnix might be geographically variable depending of the bat species. While no difference between collection sites was found for M. punicus and M. blythii, there was a significant effect of the collection sites for M. myotis. However, these results may reflect the fact that the Spinturnix were collected on M. myotis living both in sympatry or allopatry and therefore deserve further investigations.

Although Chlamydia and Chlamydia-like bacteria have been detected in many different environmental samples and organisms, the diversity of the Chlamydiae phylum is highly underestimated. Most studies have shown that both environmental and organismal samples contain Chlamydiae that certainly represent new family-level lineages, thus new Chlamydiae species [28, 29, 42, 43, 55, 58], which our study also confirmed. While $S$. myoti harbored Chlamydiae from several families, the BLAST analysis revealed that more than half of the sequences were not attributable to a known family-level lineage, suggesting they belong to a new Chlamydiales family that may be specific to $S$. myoti or to bats. Of note, an S. myoti DNA sample was also documented positive for a Chlamydiaceae, which appeared to be closely related to $C$. muridarum found in small mammals, including rodents (Rodentia: Muridae). To our knowledge, this is only the second time that a member of the Chlamydiaceae family has been discovered in an arthropod. Additionally, Chlamydia psittaci has previously been isolated in Dermanyssus gallinae, a mite of canaries [14].

In conclusion, our results suggest that the ectoparasite S. myoti may play a role as a vector of Chlamydiae, since we found a high prevalence of these strict intracellular bacteria. Our findings highlight the limited knowledge about the ecology and epidemiology of Chlamydiae and the need for further investigations. Hence, as Chlamydiae may potentially impact human and animal health, future studies should focus on the understanding of the maintenance and transmission of this bacteria in bats. Furthermore, other obligate ectoparasites, such as bat fleas (Siphonaptera: Ischnopsyllidae), bat bugs (Hemiptera: Cimicidae and Polyctenidae) and bat flies (Diptera: Nycteribiidae and Streblidae) may also potentially act as reservoirs or vectors of a wide range of bacteria $[6,38,51,52]$, including Chlamydiae.

Acknowledgements. We thank R. Arlettaz, F. Biollaz, G. Beuneux, P. Debernardi, L. Faouzi, C. Ibanes, A. Ighous, J. Juste, M. Muccedda, E. Patriarca, A. Popa-Lisseanu, J. Quetglas and above all Nadia Bruyndonckx for their intensive field work to collect Spinturnix samples.

\section{Conflicts of interest}

The authors declare that they have no conflicts of interests.

\section{References}

1. Baker AS, Craven JC. 2003. Checklist of the mites (Arachnida: Acari) associated with bats (Mammalia: Chiroptera) in the British Isles. Systematic and Applied Acarology Special Publications, 14, 1-20.

2. Baud D, Greub G. 2011. Intracellular bacteria and adverse pregnancy outcomes. Clinical Microbiology and Infection, 17, $1312-1322$.

3. Baud D, Regan L, Greub G. 2008. Emerging role of Chlamydia and Chlamydia-like organisms in adverse pregnancy outcomes. Current Opinion in Infectious Diseases, 21, 70-76.

4. Baud D, Goy G, Osterheld M-C, Borel N, Vial Y, Pospischil A, Greub G. 2011. Waddlia chondrophila: from bovine abortion to human miscarriage. Clinical Infectious Diseases, 52, 1469-1471.

5. Bayramova F, Jacquier N, Greub G. 2018. Insight in the biology of Chlamydia-related bacteria. Microbes and Infection, 20, 432-440. 
6. Brook CE, Bai Y, Dobson AP, Osikowicz LM, Ranaivoson HC, Zhu Q, Kosoy MY, Dittmar K. 2015. Bartonella spp. in fruit bats and blood-feeding ectoparasites in Madagascar. PLoS Neglected Tropical Diseases, 9, e0003532.

7. Bruyndonckx N, Dubey S, Ruedi M, Christe P. 2009. Molecular cophylogenetic relationships between European bats and their ectoparasitic mites (Acari, Spinturnicidae). Molecular Phylogenetics and Evolution, 51, 227-237.

8. Bruyndonckx N, Biollaz F, Dubey S, Goudet J, Christe P. 2010. Mites as biological tags of their hosts. Molecular Ecology, 19, 2770-2778.

9. Burnard D, Weaver H, Gillett A, Loader J, Flanagan C, Polkinghorne A. 2017. Novel Chlamydiales genotypes identified in ticks from Australian wildlife. Parasites \& Vectors, 10, 46.

10. Calisher CH, Childs JE, Field HE, Holmes KV, Schountz T. 2006. Bats: important reservoir hosts of emerging viruses. Clinical Microbiology Reviews, 19, 531-545.

11. Christe P, Arlettaz R, Vogel P. 2000. Variation in intensity of a parasitic mite (Spinturnix myoti) in relation to the reproductive cycle and immunocompetence of its bat host (Myotis myotis). Ecology Letters, 3, 207-212.

12. Christe P, Giorgi MS, Vogel P, Arlettaz R. 2003. Differential species-specific ectoparasitic mite intensities in two intimately coexisting sibling bat species: resource-mediated host attractiveness or parasite specialization? Journal of Animal Ecology, 72, 866-872.

13. Chua PKB, Corkill JE, Hooi PS, Cheng SC, Winstanley C, Hart CA. 2005. Isolation of Waddlia malaysiensis, a novel intracellular bacterium, from fruit bat (Eonycteris spelaea). Emerging Infectious Diseases, 11, 271-277.

14. Circella E, Pugliese N, Todisco G, Cafiero MA, Sparagano OAE, Camarda A. 2011. Chlamydia psittaci infection in canaries heavily infested by Dermanyssus gallinae. Experimental and Applied Acarology, 55, 329.

15. Corsaro D, Greub G. 2006. Pathogenic potential of novel Chlamydiae and diagnostic approaches to infections due to these obligate intracellular bacteria. Clinical Microbiology Reviews, 19, 283-297.

16. Corsaro D, Valassina M, Venditti D. 2003. Increasing diversity within chlamydiae. Critical Reviews in Microbiology, 29, 37-78.

17. Croxatto A, Rieille N, Kernif T, Bitam I, Aeby S, Péter O, Greub G. 2014. Presence of Chlamydiales DNA in ticks and fleas suggests that ticks are carriers of Chlamydiae. Ticks and Tick-Borne Diseases, 5, 359-365.

18. Deunff J. 1977. Observations on Spinturnicidae of occidental paleartic region (Acarina, Mesostigmata) - specificity, distribution and repartition. Acarologia, 18, 602-617.

19. Deunff J, Walter G, Bellido A, Volleth M. 2009. Description of a cryptic species, Spinturnix bechsteini n. sp. (Acari, Mesostigmata, Spinturnicidae), parasite of Myotis bechsteinii (Kuhl, 1817) (Chiroptera, Vespertilionidae) by using ecoethology of host bats and statistical methods. Journal of Medical Entomology, 41, 826-832.

20. Edgar RC. 2004. MUSCLE: multiple sequence alignment with high accuracy and high throughput. Nucleic Acids Research, 32, 1792-1797.

21. Everett KDE, Bush RM, Andersen AA. 1999. Emended description of the order Chlamydiales, proposal of Parachlamydiaceae fam. nov. and Simkaniaceae fam. nov., each containing one monotypic genus, revised taxonomy of the family Chlamydiaceae, including a new genus and five new species, and standards for the identification of organisms. International Journal of Systematic and Evolutionary Microbiology, 49, 415-440.

22. Fox J, Weisberg S. 2010. An R companion to applied regression. SAGE.
23. Giorgi MS, Arlettaz R, Guillaume F, Nusslé S, Ossola C, Vogel P, Christe P. 2004. Causal mechanisms underlying host specificity in bat ectoparasites. Oecologia, 138, 648-654.

24. Greub G. 2009. Parachlamydia acanthamoebae, an emerging agent of pneumonia. Clinical Microbiology and Infection, 15, $18-28$.

25. Greub G, Raoult D. 2004. Microorganisms resistant to freeliving Amoebae. Clinical Microbiology Reviews, 17, 413-433.

26. Han H-J, Wen H, Zhou C-M, Chen F-F, Luo L-M, Liu J, Yu $\mathrm{X}$-J. 2015. Bats as reservoirs of severe emerging infectious diseases. Virus Research, 205, 1-6.

27. Heiskanen-Kosma T, Paldanius M, Korppi M. 2008. Simkania negevensis may be a true cause of community acquired pneumonia in children. Scandinavian Journal of Infectious Diseases, 40, 127-130.

28. Hokynar K, Sormunen JJ, Vesterinen EJ, Partio EK, Lilley T, Timonen V, Panelius J, Ranki A, Puolakkainen M. 2016. Chlamydia-like organisms (CLOs) in Finnish Ixodes ricinus ticks and human skin. Microorganisms, 4, 28.

29. Hokynar K, Vesterinen EJ, Lilley TM, Pulliainen AT, Korhonen SJ, Paavonen J, Puolakkainen M. 2017. Molecular evidence of Chlamydia-Like organisms in the feces of Myotis daubentonii bats. Applied and Environmental Microbiology, 83, e02951-16.

30. Horn M. 2008. Chlamydiae as symbionts in eukaryotes. Annual Review of Microbiology, 62, 113-131.

31. Hornok S, Kovács R, Meli ML, Gönczi E, Hofmann-Lehmann R, Kontschán J, Gyuranecz M, Dán Á, Molnár V. 2012. First detection of bartonellae in a broad range of bat ectoparasites. Veterinary Microbiology, 159, 541-543.

32. Huelsenbeck JP, Ronquist F. 2001. MRBAYES: Bayesian inference of phylogenetic trees. Bioinformatics, 17, 754-755.

33. Juste J, Paunović M. 2016. Myotis punicus. The IUCN Red List of Threatened Species, 2016, E.T44864A22073410.

34. Kearse M, Moir R, Wilson A, Stones-Havas S, Cheung M, Sturrock S, Buxton S, Cooper A, Markowitz S, Duran C, Thierer T, Ashton B, Meintjes P, Drummond A. 2012. Geneious basic: an integrated and extendable desktop software platform for the organization and analysis of sequence data. Bioinformatics, 28, 1647-1649.

35. Kuo CC, Jackson LA, Campbell LA, Grayston JT. 1995. Chlamydia pneumoniae (TWAR). Clinical Microbiology Reviews, 8, 451-461.

36. Lamoth F, Jaton K, Vaudaux B, Greub G. 2011. Parachlamydia and Rhabdochlamydia: emerging agents of community-acquired respiratory infections in children. Clinical Infectious Diseases, $53,500-501$

37. Lienard J, Croxatto A, Aeby S, Jaton K, Posfay-Barbe K, Gervaix A, Greub G. 2011. Development of a new Chlamydiales-specific real-time PCR and its application to respiratory clinical samples. Journal of Clinical Microbiology, 49, 26372642.

38. Mühldorfer K. 2013. Bats and bacterial pathogens: a review. Zoonoses and Public Health, 60, 93-103.

39. Niemi S, Greub G, Puolakkainen M. 2011. Chlamydia-related bacteria in respiratory samples in Finland. Microbes and Infection, 13, 824-827.

40. Omsland A, Sixt BS, Horn M, Hackstadt T. 2014. Chlamydial metabolism revisited: interspecies metabolic variability and developmental stage-specific physiologic activities. FEMS Microbiology Reviews, 38, 779-801.

41. Pierlé SA, Morales CO, Martínez LP, Ceballos NA, Rivero JJP, Díaz OL, Brayton KA, Setién AA. 2015. Novel Waddlia intracellular bacterium in Artibeus intermedius Fruit Bats, Mexico. Emerging Infectious Diseases, 21, 2161-2163. 
42. Pillonel T, Bertelli C, Salamin N, Greub G. 2015. Taxogenomics of the order Chlamydiales. International Journal of Systematic and Evolutionary Microbiology, 65, 1381-1393.

43. Pilloux L, Aeby S, Gaümann R, Burri C, Beuret C, Greub G. 2015. The high prevalence and diversity of Chlamydiales DNA within Ixodes ricinus ticks suggest a role for ticks as reservoirs and vectors of Chlamydia-related bacteria. Applied and Environmental Microbiology, 81, 8177-8182.

44. R Core Team. 2013. R: A language and environment for statistical computing.

45. Reeves WK, Dowling APG, Dasch GA. 2006. Rickettsial agents from parasitic Dermanyssoidea (Acari: Mesostigmata). Experimental \& Applied Acarology, 38, 181-188.

46. RStudio Team. 2016. RStudio: Integrated development environment for R.

47. Rudnick A. 1960. A revision of mites of the Family Spinturnicidae (Acarina). University of California Publications in Entomology, 17, 157-284.

48. Sambrook JE, Fritsch F, Manitatis T. 1989. Molecular cloning: a laboratory manual. New York: Second Edi Cold Spring Harbor Laboratory Press.

49. Stanyukovich MK. 1997. Keys to the gamasid mites (Acari, Parasitiformes, Mesostigmata, Macronyssoidea et Laelaptoidea) parasitizing bats (Mammalia, Chiroptera) from Russia and adjacent countries. Rudolstädter Naturhistorische Schriften, 7, $13-46$.

50. Stride MC, Polkinghorne A, Miller TL, Groff JM, LaPatra SE, Nowak BF. 2013. Molecular characterization of "Candidatus Parilichlamydia carangidicola", a novel Chlamydia-Like epitheliocystis agent in yellowtail kingfish, Seriola lalandi (Valenciennes), and the proposal of a new Family, "Candidatus Parilichlamydiaceae" fam. nov. (Order Chlamydiales). Applied and Environmental Microbiology, 79, 1590-1597.

51. Stuckey MJ, Chomel BB, de Fleurieu EC, Aguilar-Setién A, Boulouis H-J, Chang C. 2017. Bartonella, bats and bugs: a review. Comparative Immunology, Microbiology and Infectious Diseases, 55, 20-29.
52. Szentiványi T, Christe P, Glaizot O. 2019. Bat flies and their microparasites: current knowledge and distribution. Frontiers in Veterinary Science, 6, 115.

53. Szubert-Kruszyńska A, Stańczak J, Cieniuch S, Podsiadły E, Postawa T, Michalik J. 2019. Bartonella and Rickettsia infections in haematophagous Spinturnix myoti mites (Acari: Mesostigmata) and their bat host, Myotis myotis (Yangochiroptera: Vespertilionidae), from Poland. Microbial Ecology, 77, 759-768.

54. Taylor HR, Burton MJ, Haddad D, West S, Wright H. 2014. Trachoma. Lancet, 384, 2142-2152.

55. Taylor-Brown A, Polkinghorne A. 2017. New and emerging chlamydial infections of creatures great and small. New Microbes and New Infections, 18, 28-33.

56. Taylor-Brown A, Vaughan L, Greub G, Timms P, Polkinghorne A. 2015. Twenty years of research into Chlamydia-like organisms: a revolution in our understanding of the biology and pathogenicity of members of the phylum Chlamydiae. Pathogens and Disease, 73, 1-15.

57. Uchikawa K, Zhang M-Y, O'Connor BM, Klompen BMH. 1994. Contribution to the taxonomy of the genus Spinturnix (Acari: Spinturnicidae), with the erection of a new genus, Emballonuria. Folia Parasitologica, 41, 287-304.

58. Vajana E, Widmer I, Rochat E, Duruz S, Selmoni O, Vuilleumier S, Aeby S, Greub G, Joost S. 2018. Indication of spatially random occurrence of Chlamydia-like organisms in Bufo bufo tadpoles from ponds located in the Geneva metropolitan area. New Microbes and New Infections, 27, 54-63.

59. Veikkolainen V, Vesterinen EJ, Lilley TM, Pulliainen AT. 2014. Bats as reservoir hosts of human bacterial pathogen, Bartonella mayotimonensis. Emerging infectious diseases, 20(6), 960.

60. Verweij SP, Kebbi-Beghdadi C, Land JA, Ouburg S, Morré SA, Greub G. 2015. Waddlia chondrophila and Chlamydia trachomatis antibodies in screening infertile women for tubal pathology. Microbes and Infection, 17, 745-748.

Cite this article as: Thiévent K, Szentiványi T, Aeby S, Glaizot O, Christe P \& Greub G. 2020. Presence and diversity of Chlamydiae bacteria in Spinturnix myoti, an ectoparasite of bats. Parasite 27, 54.

Reviews, articles and short notes may be submitted. Fields include, but are not limited to: general, medical and veterinary parasitology; morphology, including ultrastructure; parasite systematics, including entomology, acarology, helminthology and protistology, and molecular analyses; molecular biology and biochemistry; immunology of parasitic diseases; host-parasite relationships; ecology and life history of parasites; epidemiology; therapeutics; new diagnostic tools.

All papers in Parasite are published in English. Manuscripts should have a broad interest and must not have been published or submitted elsewhere. No limit is imposed on the length of manuscripts.

Parasite (open-access) continues Parasite (print and online editions, 1994-2012) and Annales de Parasitologie Humaine et Comparée (1923-1993) and is the official journal of the Société Française de Parasitologie. 